\title{
MISJA BENEDYKTYNÓW SŁOWIAŃSKICH W KOŚCIELE ŚW. KRZYŻA W KRAKOWIE
}

Ojciec św. Jan Pawel II, w encyklice Slavontm Apostoli, poświęconej postaciom ŚŚ Cyryla i Metodego, wspólpatronom Europy - obok św. Benedykta z Nursji - omawiając obrządek słowiański, wprowadzony przez nich $w$ IX wieku podczas misji apostolskiej wśród poludniowych Slowian wspomina, że obrzadek ten "byl również używany w kościele Św. Krzyża w Krakowie, przy którym osiedlili się słowiańscy benedyktyni"1. Powstaja zatem pytania czym ten obrządek wyróżnial się i jakie były w ogóle jego losy? Czy fundacja benedyktynów słowiańskich $w$ Krakowie była powrotem tego obrządku na nasze ziemie, czy było to zupełnie nowe dzieło? Jaki był cel tej fundacji?

Chrześcijaństwo metodiańskie, powstałe na obszarze Wielkich Moraw w IX wieku, w związku z działalnością misyjną ŚŚ. Cyryla i Metodego na tamtejszych terenach charakteryzuje:

1. Wlasny język liturgiczny w sakralnej Służbie Bożej, przy gloszeniu Słowa Bożego i w piśmiennictwie. Był to ówczesny dialekt poludniowoslowiański (bulgarsko-macedoński) z okolic Salonik, zwany obecnie językiem starocerkiewno-słowiańskim.

2. Wlasny alfabet słowiański, dostosowany do własności języka słowiańskiego przez św. Cyryla w oparciu o majuskulę grecka, stad zwany głagolicą.

3. Oparcie ceremeonii liturgicznych na obrzadku rzymskim.

4 Zaleźność od Stolicy Apostolskiej pod względem jurysdycznym i częściowo także dyscyplinarnym².

1 Encyklika Slazornun Aposioli Ojca św., Jana Pawla II. Rzym 1985, s. 32.

2 Ks. B. Kumor, Zagndnienie Chrześsijmístiva metodianiskiego w Paístwie Wiślan. "Zeszyty Naukowe Wydz. Humanistycznego U. Gdańskiego". Slawistyka nr 3:1982, s. 47. 
Po śmierci św. Metodego ( 885 r.) jego sufragan biskup Wiching, zwolennik lacińskiej liturgii uzyskal od papieża Stefana $V$ stanowczy zakaz używania języka slowiańskiego w liturgii kościelnej. Fakt ten spowodowal rozproszenie się uczniów i zwolenników św. Metodego. Jedni przeszli do Czech, a w większości na Półwysep Bałkański (Bułgaria, Serbia, Dalmacja, Chorwacja) z uwagi na to, że obrządek grecki był bardziej tolerancyjny wobec używania języka narodowego w liturgii.

W Bulgarii rozproszeni uczniowie i towarzysze św. Metodego zostali życzliwe przyjęci przez księcia Borysa Michała, który widzial w obrządku słowiańskim oparcie i przeciwwage dla greki w Kościele bulgarskim. Toteż liturgiczny jezzyk slowiański znalazł tu pelne zastosowanie $w$ ciagu $X$ wieku. Stal się jezzykiem piśmiennictwa zarówno duchownego, jak i świeckiego. Dzięki bliskim związkom strukturalnym $z$ narzeczami macedońskobułgarskim i wschodnio-serbskim również mocno zakorzenił się on w Serbii. $Z$ Bułgarii obrzadek słowiański zostal przeniesiony wraz $z$ wiara chrześcijańską na Ruś w II polowie $X$ wieku (chrzest Rusi 988 r.), gdzie stal się językiem panującym także $w$ piśmiennictwie. Liturgia slowiańska $w$ obrządku greckim na Rusi, podobnie jak $w$ Bułgarii i Serbii, jest $w$ powszechnym zwyczaju ${ }^{3}$.

Na poczatku $X$ wieku ten obrzadek na terenie Chorwacji i Dalmacji znalazl oparcie $w$ klasztorach benedyktyńskich. O zakorzenieniu się obrządku słowiańskiego w Chorwacji świadczy XII-wieczny przekład Reguly św. Benedykta. W polowie XIII wieku obrządek slowiański uzyskal aprobatę Stolicy Apostolskiej i múgł się swobodnie rozwijać w niektórych ośrodkach kościelnych tego kraju. Podobnie w królestwie czeskim, które przejeło tradycje państwa wielkomorawskiego, obrządek słowiański znalazł oparcie w XI wieku w klasztorze benedyktyńskim w Sazawie, założonym ok. 1032 r. przez św. Prokopa. Pielęgnowano tam obrzadek słowiański do 1095 r. W wyniku nowszych badań przyjmuje się, że w Czechach mogły istnieć luźne ośrodki tego obrządku już od czasów św. Metodego. Pod koniec XI wieku słowiańscy benedyktyni zostali usunięci z Sazawy wskutek reformy gregoriańskiej. Prawdopodobnie taki sam los spotkał także inne ośrodki związane $z$ tym obrządkiem. Usunięci mnisi mogli żyć odtąd $w$ rozproszeniu, jako mnisi wędrowni ${ }^{4}$.

Odnośnie do naszego kraju juz w polowie XIX wieku zostala zapoczałtkowana dyskusja przez J. Bandtkego i A. Bielowskiego odnośnie do penetracji obrządku słowiańskiego na tereny państwa Wiślan. Dyskusja trwa nadal, chociaż z różnym nasileniem, i brali w niej udział tacy historycy jak: Wl. Ab-

3 Stownik Starożytności Stowinúskich. T. 3(1967), s. 446.

4 Tamże, s. 447; por. także J. Wyrozumski, Benedyktyni stowiníscy ov Oleśnicy i Krakowie. W: „Zeszyty Naukowe Wydz. Humanistycznego U. Gdańskiego", Slawistyka nז 3:1982, s. 118. 
raham $^{5}$, M. Gumowski ${ }^{6}$ T. Lehr-Splawiński ${ }^{7}, M$. Rechowicz $^{8}$ i inni. Sformulowano szereg hipotez, które nie mają pozytywnego oparcia w źródlach. Wszystkie konstrukcje wydaja się przemawiać za tym, że działalność św. Metodego objęla Polskę poludniowa, ale nie można tego udowodnić. Pod wplywem Rusi obrządek słowiański mógl być tu i ówdzie zaprowadzony i tolerowany przez kler laciński, ale nie mógl się utrzymać bez własnej organizacji kościelnej i nie mógł zapuścić głębszych korzeni. Dlatego też B. Kumor konkluduje, że można przyjąć istnienie chrześcijaństwa metodiańskiego $w$ plemiennym państwie Wiślan. „Nie ma jednak żadnych przckonywajacych dowodów, które by pozwolily na przyjęcie jego rozwoju i dluższego trwania oraz na wykształcenie się jego struktury hierarchicznej w Polsce X i XI stulecia". W oparciu o powyższe wywody należy przyjác, że założenie klasztoru benedyktynów slowiańskich w Krakowie było zupelnie nowym przedsięwzięciem fundatorów, Wł. Jagielly i Jadwigi, a nie nawiązaniem do dawnej tradycji ${ }^{9}$.

Fundacja klasztoru i kościoła Św. Krzyża w Krakowie dla benedyktynów obrządku słowiańskiego była przedmiotem zainteresowań badawczych niejednego historyka, zajmującego się naszą przeszłością narodową z różnych okazji ${ }^{10}$. Poszerzenie i pomnożenie informacji $w$ tym względzie jest raczej już malo prawdopodobne $z$ uwagi na ograniczone możliwości badawcze i niklą podstawę źródlową. Wszelkie informacje i wysunięte wnioski będa więc tylko raczej przypomnieniem niż ubogaceniem istniejącego poglądu i rozumienia.

Podstawowym źródłem dla omawianego problemu są dziela Jana Dlugosza (1415-1480) ${ }^{11}$, w których podaje on pełny tekst dokumentu fundacyjnego wraz ze spostrzeżeniami i wiadomościami z czasów mu współczesnych. Te przekazy historyczne były również podstawa wszystkich innych opracowań tego tematu. Jak podaje Długosz, król Wladysław Jagiełło wraz ze swoja żoną Jadwiga aktem fundacyjnym z dnia 28 lipca 1390 r. zaklada, buduje i uposaża

5 Wh. Abraham, Organizacjn Kościołn w Polsce do potoury XlI ivieku. Lwów 1893, s. 160 i n.

6 M. Gumowski, Szkice numizmmtyczno-historyczue w XI w. W: Prace Komisji Historycznej Poznańskiego Towarzystwa Przyjaciól Nauk. T. 3, z. 2. Poznań 1924, s. 80 i n.

7 T. Lehr-Splawiński, Patrinchat Focjuszn a sprary slowiniskie w IX arieku, w: Rozpratuy i szkice z dziejów kultury Stowian. Warszawa 1954, s. 185-187; Tenże: C $z y$ sq slady istnienin liturgii cyrylometodianskiej w dniwnej Polsce? "Slavia". T. 25:1956; tenże: Nown faza dyskusji o zagadnieniu liturgii stowinískiej w dawntej Polsce. „Nasza Przeszlość". T. 7:1958.

8 M. Rechowicz, Sprawi obrzalku cyrylo-metodiańskiego wo Polsce. W: Pastori et Magistro. Lublin 1956 , s. 85 .

9 Ks. B. Kumor, dz. cyt., s. 54 .

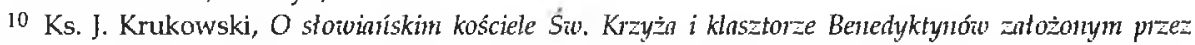
Jadivige i Jagiellę na Kleparzu w Krakowie 1390 r. Kraków 1886; J. Wyrozumski, dz. cyt.

11 J. Dlugosz, Roczniki czyli Kroniki Stanunego Królestwa Polskiego Ks. X. 1370-1405. Warszawa 1981, s. 238-240; tenże: Liber Beneficiorum Dioecesis Cracotriensis... T. 3. Monasteria. Cracoviae 1864, s. 226-7. 
klasztor benedyktynów slowiańskich $w$ mieście Kleparzu, założonym przez króla Kazimierza Wielkiego obok Krakowa. Wprawdzie w dokumencie fundacyjnym występuje tylko sam król Wladyslaw Jagielło, to jednakże Dlugosz uzupełnia zawarte $w$ tym dokumencie wiadomości informacja wlasną o roli królowej Jadwigi oraz biskupa krakowskiego Piotra Wysza w dojściu fundacji do skutku. Nasuwa się problem, jak wyjaśnić udzial Piotra Wysza w tej sprawie, skoro zostal on biskupem krakowskim dopiero 19. XII. 1392 r. J. Wyrozumski tlumaczac tę trudność ivysuwa podwójna alternatywę. Wymieniajac biskupa krakowskicgo Piotra Wysza Dlugosz albo chcial zaznaczyć, że byl on rzecznikiem sprowadzenia benedyktynów slowiańskich do Krakowa, zanim jeszcze zostal biskupem krakowskim, albo, co również będzie prawidłowe, już jako biskup ordynariusz krakowski przyczynił się do organizacji tej fundacji, której realizacja trwała przecież kilka lat i miejscowy ordynariusz musial $w$ tej sprawie odegrać ważną role ${ }^{12}$.

Czym należy tlumaczyć fakt, że ufundowano w Krakowie klasztor benedyktynów w obrządku słowiańskim, skoro obok Krakowa w pobliskim Tyńcu istnialo już od trzech wieków opactwo benedyktyńskie obrzadku lacińskiego? Jak uzasadnia te sprawę Dlugosz? W jego Rocznikach... Królestzon Polskiego czytamy m.in.: "Król polski Władyslaw Il ze swą żoną Jadwiga... pragnẹli rozszerzyć... na Królestwo Polskie to niezapomniane dobrodziejstwo, którym laska Zbawiciela wyniosła i w przedziwny sposób wslawila naród Słowiański, obdarzając go niezwykła laską, że wszystkie święte obrzędy i nabożeństwa tak nocne jak i dzienne, a nawet Tajemnica Mszy świętej moga być odprawiane w jego języku... Chcieli też okazać wdzięczność wobec Boga i zwykła hojność za rozliczne zwycięstwa i dobrodziejstwa wyświadczone im przez Boga w tym roku. Zachęceni przykladem slowiańskiego klasztoru św. Benedykta, który istnieje w mieście Pradze... zakładaja, buduja i uposażaja mający przestrzegać reguły pod wezwaniem św. Krzyża w mieście Kleparzu..."13.

Należy tu jeszcze dodać, że wcześniej, bo w 1380 r. książę oleśnicki i kozielski Konrad II - za zgodą wladz kościelnych - sprowadził do Oleśnicy na Śląsku benedyktynów słowiańskich z Pragi czeskiej do ufundowanego przez siebie klasztoru.

Z uwagi na wzmiankę Długosza o opactwie Benedyktynów Slowiańskich w Pradze, ufundowanym przez cesarza Karola IV (1355-1378) w 1347 r. na mocy bulli papieża Klemensa VI (1342-1352) wydaje się rzecza nieodzowna przytoczc nie także uzasadnienia tego aktu. Bulla erekcyjna Klemensa VI podaje następujace racje: „W Slowiańszczyźnie i w niektórych innych stronach poslugujacych się językiem słowiańskim są czytane i śpiewane msze św. i godziny kanoniczne ku chwale Chrystusa w ich języku ludowym za zezwoleniem i dopuszczeniem

12 Por. J. Wyrozumski, dz. cyt., s. 115.

13 J. Dlugosz, Roczniki..., s. 238-239. 
Stolicy Apostolskiej, a liczne klasztory tamże i pomieszczenia mnichów czarnych św. Benedykta i innych reguł utrzymujacych ten rytuał $z$ dawnego zwyczaju aż po dzien dzisiejszy z powodu zaburzeń $i$ wojen $w$ tych stronach zostaly zniszczonc i zniweczone. Mnisi i bracia wspomnianych zgromadzeń nie moga działać ku pożytkowi ani Bogu, ani chrześcijanom i nie mając możliwości spokojnego dzierżenia swoich klasztorów, pozostaja wẹdrowni, przez co w tych stronach ulega pomniejszeniu kult Boży i wiara chrześcijańska". Dalej bulla zwraca uwage, że na terenie Królestwa Czeskiego i krajów sąsiednich żyją liczni schizmatycy i niewierni, posługujący się językiem słowiańskim. Nie rozumieją oni Slowa Bożego gloszonego w języku lacińskim. Stąd też wynika konieczność zainstalowania działania benedyktynów w obrządku słowiańskim, jako zdolnych do gloszenia Ewangelii wśród tych ludów"14.

Zachodzi pytanie o jakich schizmatyków i heretyków chodzi w tej bulli? Wiemy, że mianem schizmatyków określano wyznawców Kościola Prawosławnego. J. Wyrozumski przyjmuje, że z uwagi na luźny kontakt $z$ wiernymi Kościola Prawosławnego $w$ krajach Korony Czeskiej chodziło o coś więcej w wymienionej bulli dlatego słowiańskie ognisko ruchu heretyckiego lączy z ruchem bogomilskim, który żywo rozwijał się w Bułgarii od schyłku X wieku. Wprawdzie ruch ten opicrał się na dualizmie manichejskim, ale dzięki językowi słowiańskiemu w liturgii rozwijał się w Bułgarii, a następnie przedostał się do Serbii i dalej na Zachód. W Bośni, Chorwacji i Dalmacji ruch ten przyjał pewne odrębne cechy i utworzył własna organizacje kościelna. Znane jest również oddziaływanie tego ruchu w Hercegowinie i na Węgrzech. Tenże badacz podaje, że bogomilizm miał swój bezpośredni wplyw także na rozwój zakonu benedyktyńskiego w obrządku slowiańskim w Dalmacji i Chorwacji. Natomiast jeśli chodzi o fundacje praskă, uważa, że nie ma ona bezpośredniego związku $\mathrm{z}$ ruchem bogomilskim, $\mathrm{z}$ uwagi na brak większego wpływu tego ruchu na Czechy. Rzeczywisty motyw założenia klasztoru obrządku słowiańskiego w Pradze mial swe uzasadnienie $w$ rodzących się aspiracjach narodowych ludu czeskiego, lączącego obrządek łaciński z patrycjatem niemieckim. Istotnie konwent benedyktynów slowiańskich w Pradze przyczynil się do powstania ruchu husyckiego i odrodzenia narodowego w Czechach. Tym należy tlumaczyć jego przetrwanie podczas burzy husyckiej w krajach Korony Czeskiej. Dopiero później opactwo praskie benedyktynów slowiańskich podupadło i w wieku XVII przybyli tu benedyktyni obrządku lacińskiego"15.

Bardzo istotnym problemem dla naszego tematu jest ustalenie motywu, jakim kierowała się para królewska, sprowadzając benedyktynów slowiańskich z Pragi do Krakowa. Wydaje się, że pewien wpływ na fundację krakowską miał książe oleśnicko-kozielski Konrad II, który również sprowadzil Benedykty-

1t Por. J. Wyrozumski, dz. cyt., s. 117.

15 Tamze, s. 120-122. 
nów Słowiańskich z Pragi Czeskiej w dziesięć lat wcześniej. Był on silnie związany z królem Wladysławem Jagiełlo w poczatkowym okresie jego panowania. Posłowal $w$ imieniu króla do Zakonu Krzyżackiego oraz brał udzial wraz z królem $w$ akcji chrystianizacji Litwy w $1387 \mathrm{r}^{16}$.

Mogły tu odgrywać, i chyba wplywały na decyzje, osobiste zainteresowania i zamilowania króla i królowej. Sam Wladysław Jagiello byl wychowany przez matke prawosławna Juliannę, księżnę twerska ${ }^{17}$. Ciagle kontakty z Rusinami wyrobily u niego zamiłowanie do kultury słowiańskiej, czego wyrazem byla obecność licznych artystów ruskich na jego dworze. Również królowa Jadwiga interesowala się kultura slowiańską. Wprawdzie $w$ linii męskiej była Andegawenka, ale jej babka była Piastówną, matka Bośniaczką, a mąż władca litewsko-ruskim ${ }^{18}$.

Najważniejszą i chyba główna przyczyna tego przedsięwzięcia była najprawdopodobniej sprawa unii z Kościolem Prawoslawnym. Myśl unijna bardzo usilnie popieral Jagiełł. Wielkim rzecznikiem unii w państwie Jagiellonów w nieco późniejszym okresie był metropolita kijowski, Grek z pochodzenia, Izydor. Po zawarciu unii na soborze florenckim papież Eugeniusz IV (1431-1447) wyniósł metropolite lzydora w 1439 r. do godności kardynala i legata papieskiego na Polskę, Ruś, Litwę i i Inflanty ${ }^{19}$.

Za przyjęciem uzasadnienia, że z konwentem benedyktynów slowiańskich w Krakowie łączono misję chrześcijańską w Wielkim Księstwie Litewskim przemawiaja także okoliczności geograficzno-demograficzne. W XIV wieku Wielkie Księstwo Litewskie obejmowalo rozlegle tereny między Danią, Zakonem Krzyżackim, Zakonem Mieczowym, Księstwem Moskiewskim i Tatarami a Królestwem Polskim. Na tym obszarze liczącym okolo 800 tysięcy $\mathrm{km}^{2}$ ludność etnicznie litewska, mieszkająca na rdzennej Litwie i Ż mudzi, dotychczas pogańska, stanowila zaledwie ok. 20\%. Za Giedyminowiczów włączono do Wielkiego Księstwa Litewskiego kolejno Polesie, Podlasie, Brześć, Połock, cala Ukrainę, Wolyń, Podole. Te olbrzymie tereny zamieszkiwała ludność ruska, już od dawna schrystianizowana w obrządku prawosławnym. Oprócz podbijania ziem ruskich sila, umacniano tam swoje wpływy także przez politykę małżeństw dynastycznych, glównie litewskich książąt z ruskimi księżniczkami. Nasuwa się nawet pytanie, dlaczego prawosławie nie stało się religia Litwinów, mimo tak silnego powiązania ziem Wielkiego księstwa z prawosłauriem? Kościól Wschodni nie podjał nigdy dzialalności misyjnej na rdzennej Litwie. Żaden wielki książę litewski nie przyjął prawosławia

16 Tamże, s. 123.

17 Por. Z. Wdowiszewski, Gentealogin Jagiellonów. Warszawa 1968, s. 14.

18 Por. J. Powierski, Roln dwont jngiellońskiego w kontaktach Polski z krẹgiem piśniennictwa cerkiewno-słowianiskiego. "Zeszyty Naukowe Wydz. Humanistycznego U. Gdańskiego". Slawistyka nr 3:1982, s. 153-155.

19 Por. ks. W. Schenk, Kult liturgiczny świętych Cyryla i Metodego w Polsce, tamże: s. 59. 
w ciagu XIII i XIV wieku, chociaż czynili to członkowie ich rodzin. Niewatpliwie wynikało to $z$ obawy rutenizacji Litwy.

W takiej sytuacji obrządek słowriański, zatwierdzony przez Stolicę Apostolska, przedstawial się jako skuteczny środek slużący zbliżeniu między Kościolem Wschodnim a Kościołem Zachodnim. Ten wniosek zdaje się potwierdzać wielki rozmach, z jakim planowano nową fundację krakowską. Konwent krakowski slowiańskich benedyktynów mial liczyć 30 mnichów, oprócz domowników i służby. Na ten fakt zwracano uwage przy okazji obchodów 500-lecia chrztu Litwy ${ }^{20}$.

Jak przebiegala realizacja planu fundacyjnego? - Jako początkowe uposażenie król Władysław Jagiełlo aktem fundacyjnym z dnia 28 lipca 1390 nadal konwentowi 20 grzywien dochodu rocznego z cla krakowskiego, po 5 grzywien kwartalnie. Długosz podaje, że fundatorzy przewidywali większe uposażenie dla tak licznego konwentu mnichów, domowników i slużby oraz calego zaplecza. Być może liczono na ofiarność możnych, co jednak nie nastąpiło. Dla zakonników wybudowano na razie drewniany dom z ogrodem, do którego wprowadziło się kilku mnichów przybylych z Pragi. Pod kościól polożono fundamenty i wybudowano chór oraz zakrystię. Później otoczono plac murem z cegły. W zamian za to uposażenie mnisi byli zobowiązani do odprawiania $w$ każdym tygodniu dwóch mszy świętych $w$ intencji zbawienia fundatorów. Przewidywano także dokończenie budowy klasztoru ze wszystkimi celami i budynkami gospodarczymi. Po śmierci królowej Jadwigi ustal pierwotny zapal. Jagiello odstąpil od zrealizowanych częściowo zamiarów, nie dokoniczyl fundacji i nie wymurowal obszerniejszego klasztoru ${ }^{21}$.

$W$ tej kaplicy pod wezwaniem Św. Krzyża rozpoczęto już w 1392 r. - nie czekając na dokończenie budowy - odprawianie nabożeństw $w$ języku słowiańskim. Wedlug P.H. Pruszcza kościól nigdy nie zostal wykończony. Wkrótce splonąl i przez półtora wieku leżał w gruzach. Potem wystawiono na tym miejscu drewnianą kaplicę, którą inkorporowano w 1505 r. do kolegiaty Św. Floriana ${ }^{22}$.

Dlugosz podaje, że do jego czasów slowiańscy benedyktyni zarządzali kościolem Św. Krzyża, odprawiali w nim nabożeństwa, msze św., godziny kanoniczne i inne ceremonie kościelne bądź to śpiewane, bądź recytowane, w języku slowiańskim²3. Obrządek ten musial ustać gdzieś w latach 1470-1480, gdyż nasz dziejopis uzupełnia swój przekaz informacją, że fundację powierzono księdzu diecezjalnemu Jerzemu Litwoszowi, który nią administruje "non sine scandalo et iniuria dotatorum" 24 .

20 Por. ks. J. Krukowski, O slowianiskim kościele Śzv. Krzył̇a..., s. 12; J. Dzikówna, Klepurz do 1528 r. Kraków 1932, s. 93.

21 J. Dlugosz, Liber Beneficiorum..., t. 3, s. 226.

22 Por. P.H. Pruszcz, Klejnoty stołeczntego minsta Krakowa albo kościoły... 1745. Kraków 1983, s. 161.

23 J. Dlugosz, Roczniki..., s. 239.

2* Tenże: Liber Betteficiorum..., t. 3, s. 226. 
Z akt wizytacyjnych dekanatu krakowskiego z 1599 r. z czasów kard. Jerzego Radziwilla wynika, że w tym okresie kościolem Św. Krzyża administrowali wikariusze kolegiaty Św. Floriana. Uposażenie stanowiło nadal 20 grzywien z cel krakowskich. W zamian za uposażenie ciażyl na kaplicy obowiazek odprawiania (legere) tygodniowo dwóch mszy św. (jedna o Trójcy Świętej, a druga o św. Krzyżu) za zmarlych fundatorów ${ }^{25}$. Ale już wtedy zatarla się tradycja, że był to kiedyś klasztor Slowiańskich Benedyktynów. Ostatecznie kościół Św. Krzyża został rozebrany w 1817 r. z polecenia władz austriackich a na tym miejscu wybudowano domy mieszkalne.

$\mathrm{O}$ istnieniu historycznego klasztoru benedyktynów słowiańskich w Krakowie - poza nielicznymi przekazami źródłowymi - świadczy obecnie tylko nazwa sasiadującego skweru jako "Plac Słowiański” oraz niewielka tablica z czarnego marmuru na domu przy ulicy Dlugiej 36 z napisem: "Na tem miejscu stał kościół slowiański Św. Krzyża wraz z klasztorem benedyktynów r. 1390 przez Jadwige i Jagiełle na pamiątkę chrztu Jagiełły zbudowany a w $\mathrm{r}$. 1817 zburzony. W 500-letnią rocznicę tego chrztu obchodzoną 14 lutego $1886 \mathrm{r}$. tę tablicę kladą obywatele miasta Krakowa".

Jak ocenić krótki żywot fundacji slowiańskiej w Krakowie? Sama - idea założenia klasztoru i sprowadzenia mnichów w obrządku slowiańskim jest wyrazem szerokich horyzontów myślowych i dalekosiężnych planów politycznych pary królewskiej Jagielly i Jadwigi. Z dalszych losów dzieła wynika, że jego inspiratorką była królowa Jadwiga. Gdy jej zabrakło, przedsięwzięcie które mogło wydać błogoslawione owoce, nie znalazło poparcia u innych możnowladców, a zwłaszcza u polskich hierarchów. Świadczy to u krótkuwzroczności ludzi odpowiedzialnych za ówczesne losy Kościoła w naszym kraju. Niewatpliwie obrządek słowiański stanowił wyrwę w jednolitym obrządku lacińskim. Należy także brać pod urvagę i to, że cały wysiłek misyjny Kościola katolickiego w Polsce byl skierowany na nawrócenie pogańskiej Litwy, a tego dokonywano $w$ obrządku lacińskim. Istnial także lęk przed nowością, której konsekwencje byly trudne do przewidzenia. Lęk może i słuszny, bo wiemy, że w Czechach obrządek slowianski przetrwał dłużej niż $w$ Polsce, mimo zalamania się ruchu husyckiego, związanego właśnie $z$ językiem narodowym. W naszym kraju brak było tej tradycji i przedsięwzięcie pozostawione sobie zostało skazane na powolny upadek. Nieco później, pod koniec XVI wieku, idea powiazania prawoslawia na Ziemiach Ruskich z Rzymem odżyła w dziele Unii Brzeskiej. I ona również nie znalazła poparcia $w$ szerszych kręgach polskiej hierarchii kościelnej i nie wykorzystano $w$ pelni możliwości, jakie stworzyła w aspekcie religijnym, politycznym i społecznym.

25 Aktn Wizytacji Deknututu Krakouskiego... z polecenia kard. J. Rndziwithn z 1599 r. Cz. 1. Wyd. Cz. Skowron, Materiaty do Dziejów Kościoła ü Polsce. Lublin 1965, s. 103-104. 